A Novel Phot ocat al yt i c Syst em Const ruct ed Usi ng Eosi $\mathrm{n} \mathrm{Y}$, Ti t ani um Di oxi de, and Keggi $n$ - Type Pl at i num( I I ) - and Al umi nunt( I I I ) - Coor di nat ed Pol yoxot ungst at es for Hydr ogen Product i on from Wat er Under Vi si bl e Li ght I rradi at i on

\begin{tabular}{|c|c|}
\hline 著者 & Hat tor i Shot a, I har a Yuki, Kat o Chi ka Nozaki \\
\hline $\begin{array}{l}\text { jour nal or } \\
\text { publ i cat } i \text { on } t i t l e\end{array}$ & Cat al ysi s Let ters \\
\hline vol une & 145 \\
\hline number & 9 \\
\hline page $r$ ange & 17031709 \\
\hline year & 2015-07-09 \\
\hline 出版者 & Spr i nger \\
\hline 権利 & $\begin{array}{l}\text { (C) Spr i nger Sci ence+Busi ness Medi a New York } \\
\text { 2015. The fi nal publ i cat i on i s avai I abl e at } \\
\text { Spr i nger vi a } \\
\text { ht t p: //dx. doi . or g/10.1007/s10562-015- } 1574-8\end{array}$ \\
\hline URL & ht t p: //hdl . handl e. net /10297/9763 \\
\hline
\end{tabular}




\section{A Novel Photocatalytic System Constructed using Eosin Y, Titanium Dioxide, and Keggin-Type Platinum(II)- and Aluminum(III)-coordinated Polyoxotungstates for Hydrogen Production from Water under Visible Light Irradiation}

Shota Hattori • Yuki Ihara • Chika Nozaki Kato

S. Hattori • Y. Ihara • C. N. Kato (corresponding author)

Department of Chemistry, Faculty of Science, Shizuoka University, 836 Ohya, Suruga-ku, Shizuoka 422-8529, Japan

e-mail: sckatou@ipc.shizuoka.ac.jp (C. N. Kato)

C. N. Kato

Green Chemistry Research Division, Research Institute of Green Science and Technology, Shizuoka University, 836 Ohya, Suruga-ku, Shizuoka 422-8529, Japan 
Abstract: A novel photocatalytic system constructed using Eosin Y, $\alpha$-Keggin-type diplatinum(II)-coordinated tungstophosphate $\mathrm{Cs}_{3}\left[\alpha-\mathrm{PW}_{11} \mathrm{O}_{39}\left\{\text { cis- } \mathrm{Pt}\left(\mathrm{NH}_{3}\right)_{2}\right\}_{2}\right] \cdot 8 \mathrm{H}_{2} \mathrm{O}$ (Cs-Pt-1), $\alpha$-Keggin-type mono-aluminum(III)-coordinated tungstosilicate $\mathrm{K}_{5}[\alpha-$ $\left.\mathrm{SiW}_{11}\left\{\mathrm{Al}\left(\mathrm{OH}_{2}\right)\right\} \mathrm{O}_{39}\right] \cdot 7 \mathrm{H}_{2} \mathrm{O}(\mathbf{K}-\mathbf{A l}-\mathbf{1})$, and titanium dioxide achieved a steady rate of hydrogen evolution with highly effective utilization of platinum sites from aqueous triethanolamine solution during a long-term visible light irradiation.

Graphical Abstract

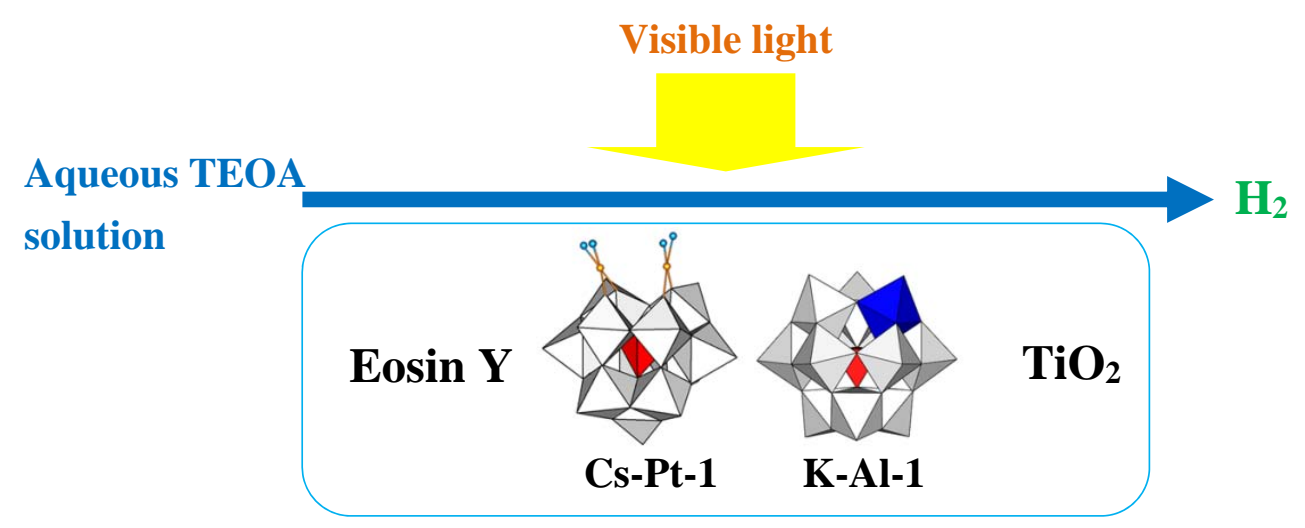

Keywords Diplatinum(II) complex $\bullet$ Aluminum(III) complex $\bullet$ Polyoxometalate $\bullet$ Hydrogen evolution • Visible light

\section{Introduction}

Since Honda and Fujishima first demonstrated a photo-electrochemical cell, which consisted of a $\mathrm{TiO}_{2}$ photo-anode and platinum cathode, that decomposed water into hydrogen and oxygen under ultraviolet (UV) irradiation with an external bias [1], the development of efficient photocatalysts, especially those that work under visible light irradiation, for the production of hydrogen from water has attracted attention of researchers working in the fields of solar light energy utilization and storage [2-4]. Platinum is known to be the most effective co-catalyst to construct efficient photocatalytic systems for producing hydrogen because platinum promotes the separation of photo-generated electrons and holes and improves the efficiency of photocatalysis when it acts as the active site for hydrogen evolution [5]. Therefore, further 
improving the effective utilization of platinum sites is an important research objective.

To achieve an atomic-level utilization of platinum sites, we have earlier focused on the use of lacunary polyoxometalates as all-inorganic ligands because the coordination of metal ions and organometallic fragments into the vacant site(s) of lacunary polyoxometalates can be used to construct and stabilize well-defined metal centers [6-8]. Recently, we synthesized the cesium salt of $\alpha$-Keggin diplatinum(II)-coordinated tungstophosphate, $\mathrm{Cs}_{3}\left[\alpha-\mathrm{PW}_{11} \mathrm{O}_{39}\{\right.$ cis$\left.\left.\mathrm{Pt}\left(\mathrm{NH}_{3}\right)_{2}\right\}_{2}\right] \cdot 8 \mathrm{H}_{2} \mathrm{O}$ (Cs-Pt-1), and demonstrated its photocatalytic performance for hydrogen evolution from aqueous EDTA.2Na (ethylenediaminetetraacetic acid disodium salt) solution under visible light irradiation $(\geq 400 \mathrm{~nm})$ in the presence of titanium dioxide [9]. During the photoreactions, the platinum compound acted as both a photosensitizer and a co-catalyst, and exhibited high turnover numbers (TONs) when calculated on the basis of the amount of platinum atoms. The stability of the platinum centers was superior to cisplatin (cisdiamminedichloroplatinum(II)) under light irradiation. However, no reaction was observed under visible light irradiation at longer wavelengths because Cs-Pt-1 only absorbs light at approximately $400 \mathrm{~nm}$ in the visible region.

Here, we demonstrated the photocatalytic performance of Cs-Pt-1 in the presence of Eosin Y (EY) for hydrogen evolution from aqueous triethanolamine (TEOA) solutions under visible light irradiation ( $\lambda=\geq 400 \mathrm{~nm}$ and $\geq 440 \mathrm{~nm}$ ). Although the rapid decomposition of EY under light irradiation caused a significant deactivation in the initial step, Li and co-workers recently reported that $\alpha$-Keggin mono-aluminum-substituted tungstosilicate, $\left[\alpha-\mathrm{SiW}_{11}\left\{\mathrm{Al}\left(\mathrm{OH}_{2}\right)\right\} \mathrm{O}_{39}\right]^{5-}$ (Al-1), stabilized EY via the coordination of EY onto the mono-aluminum site in polyoxoanion Al-1 [10]. Thus, we also investigated the photocatalytic activities of the Cs-Pt-1/EY system in the presence of the Keggin- and Dawson-type mono- and multi-aluminum-coordinated polyoxometalates, $\quad \mathrm{K}_{5}\left[\alpha-\mathrm{SiW}_{11}\left\{\mathrm{Al}\left(\mathrm{OH}_{2}\right)\right\} \mathrm{O}_{39}\right] \cdot 7 \mathrm{H}_{2} \mathrm{O} \quad(\mathbf{K}-\mathrm{Al}-\mathbf{1}), \quad\left[\left(\mathrm{CH}_{3}\right)_{4} \mathrm{~N}\right] 4[\alpha-$ $\left.\mathrm{PW}_{11}\left\{\mathrm{Al}\left(\mathrm{OH}_{2}\right)\right\} \mathrm{O}_{39}\right] \cdot 8 \mathrm{H}_{2} \mathrm{O} \quad$ (TMA-Al-2), $\quad \mathrm{K}_{6} \mathrm{Na}_{2}\left[\left(\mathrm{~A}-\mathrm{PW}_{9} \mathrm{O}_{34}\right)_{2}\left\{\mathrm{~W}(\mathrm{OH})\left(\mathrm{OH}_{2}\right)\right\}-\right.$ $\left.\left\{\mathrm{Al}(\mathrm{OH})\left(\mathrm{OH}_{2}\right)\right\}\left\{\mathrm{Al}(\mu-\mathrm{OH})\left(\mathrm{OH}_{2}\right)_{2}\right\}_{2}\right] \cdot 19 \mathrm{H}_{2} \mathrm{O}(\mathbf{K N a}-\mathrm{Al}-3),\left[\left(\mathrm{CH}_{3}\right)_{4} \mathrm{~N}\right] 6 \mathrm{H}\left[\alpha_{2}-\mathrm{P}_{2} \mathrm{~W}_{17}\left\{\mathrm{Al}\left(\mathrm{OH}_{2}\right)\right\}-\right.$ $\left.\mathrm{O}_{61}\right] \cdot 11 \mathrm{H}_{2} \mathrm{O}$ (TMA-Al-4), and $\mathrm{K}_{6}\left[\mathrm{~B}-\alpha-\mathrm{H}_{3} \mathrm{P}_{2} \mathrm{~W}_{15}\left\{\mathrm{Al}\left(\mathrm{OH}_{2}\right)\right\}_{3} \mathrm{O}_{59}\right] \cdot 14 \mathrm{H}_{2} \mathrm{O}$ (K-Al-5). Finally, we constructed a novel photocatalytic system that achieved a steady rate of hydrogen production during a long-term light irradiation with highly effective utilization of the platinum sites over a wide visible region $(\lambda=\geq 400 \mathrm{~nm}, \geq 440 \mathrm{~nm}$, and $\geq 500 \mathrm{~nm})$. The molecular structures of Cs-Pt1, K-Al-1, TMA-Al-2, KNa-Al-3, TMA-Al-4, and K-Al-5 are shown in Figure 1. 


\section{Experimental}

\subsection{Materials}

Compounds Cs-Pt-1, K-Al-1, TMA-Al-2, KNa-Al-3, K-Al-5, and $\mathrm{K}_{8}\left[\alpha-\mathrm{SiW}_{11} \mathrm{O}_{39}\right] \cdot 17 \mathrm{H}_{2} \mathrm{O}$ were synthesized using literature methods [9, 11-15]. Compound TMA-Al-4 was synthesized analogously to the published method for $\mathrm{K}_{7}\left[\alpha_{2}-\mathrm{P}_{2} \mathrm{~W}_{17}\left\{\mathrm{Al}\left(\mathrm{OH}_{2}\right)\right\} \mathrm{O}_{61}\right] \cdot 14 \mathrm{H}_{2} \mathrm{O}$ [12]; the synthetic details and characterization results are shown in the Supporting Information. The number of solvated water molecules was determined using thermogravimetric/differential thermal analysis (TG/DTA). All of the reagents and solvents were obtained from commercial sources and used as received. Titanium dioxide (anatase:rutile $=80: 20$ ) was obtained from Wako Pure Chemical Industries, Ltd.

\subsection{Instrumentation/Analytical Procedures}

Elemental analysis was performed using a Mikroanalytisches Labor Pascher instrument (Remagen, Germany). The samples were dried overnight at ambient temperature under $10^{-3}$ $10^{-4}$ Torr vacuum before analysis. The infrared spectra were recorded on a Perkin Elmer Spectrum 100 FT-IR spectrometer on $\mathrm{KBr}$ disks at ambient temperature. TG/DTA data were obtained using Rigaku Thermo Plus 2 TG/DTA TG 8120 and Rigaku Thermo Plus EVO2 TG/DTA $81205 Z$ instruments under air while increasing the temperature from 20 to $500{ }^{\circ} \mathrm{C}$ at a rate of $4{ }^{\circ} \mathrm{C} / \mathrm{min}$. The solution ${ }^{31} \mathrm{P}-\left\{{ }^{1} \mathrm{H}\right\}(242.95 \mathrm{MHz})$ nuclear magnetic resonance (NMR) spectra were recorded in 5-mm tubes on a JEOL ECA-600 NMR spectrometer. The ${ }^{31} \mathrm{P}$ NMR spectra were measured in $\mathrm{D}_{2} \mathrm{O}$ with reference to an external standard of $85 \% \mathrm{H}_{3} \mathrm{PO}_{4}$ in a sealed capillary. Chemical shifts were reported as negative on the $\delta$ scale for resonances upfield of $\mathrm{H}_{3} \mathrm{PO}_{4}(\delta 0)$. Solution ultraviolet-visible (UV-Vis) spectra were recorded using a Perkin-Elmer Spectrum Lambda 650 spectrophotometer.

\subsection{Photocatalytic Reaction Experiments}


Typical photocatalytic reactions were carried out at $25^{\circ} \mathrm{C}$. Cs-Pt-1 $(0.2-1.0 \mu \mathrm{mol}$ of Pt), EY $(2.5 \mu \mathrm{mol})$, and aluminum-coordinated polyoxotungstates $(2.5 \mu \mathrm{mol})$ were dissolved in 10 $\mathrm{mL}$ of $100 \mathrm{mM}$ aqueous TEOA solution at $\mathrm{pH}$ 7.0. The solution was placed into a glass reaction vessel, which was connected to a Pyrex conventional closed gas circulation system $\left(245.5 \mathrm{~cm}^{3}\right)$. The photoreaction was initiated by light irradiation using a $300 \mathrm{~W}$ Xe lamp equipped with a cut-off filter $\left(\lambda=\geq 400 \mathrm{~nm}, \geq 440 \mathrm{~nm}\right.$, or $\geq 500 \mathrm{~nm}$ ). $\mathrm{H}_{2}, \mathrm{O}_{2}, \mathrm{CO}$, and $\mathrm{CH}_{4}$ evolution were analyzed using GC (TCD, Molecular Sieve 5A stainless columns). The samples were assigned after comparing them with standard samples analyzed under the same conditions. The turnover number (TON) was calculated as $2\left[\mathrm{H}_{2}\right.$ evolved (mol)]/[Pt atoms (mol)].

\section{Results and Discussion}

We examined the evolution of hydrogen from $100 \mathrm{mM}$ aqueous TEOA solution (pH 7.0) under light irradiation $(\geq 400 \mathrm{~nm})$, as shown in Table 1. TEOA was used as an electron donor. During the photoreactions, the platinum and aluminum compounds and EY were soluble in the aqueous TEOA solution. Hydrogen was formed with $100 \%$ selectivity, and $\mathrm{O}_{2}, \mathrm{CO}_{2}, \mathrm{CO}$, and $\mathrm{CH}_{4}$ were not detected under these reaction conditions. When a mixture of Cs-Pt-1 (0.2 $\mu$ mol of Pt $)$ and EY $(2.5 \mu \mathrm{mol})$ was used as a catalyst, the initial reaction rates increased linearly; however, a rapid deactivation was observed after $4 \mathrm{~h}$, as shown in Figure 2. The turnover frequency (TOF $=$ TON $\mathrm{h}^{-1}$ ) was $315 \mathrm{~h}^{-1}$ after $1 \mathrm{~h}$, and the TON became 781 after $6 \mathrm{~h}$. When cisplatin $(1.0 \mu \mathrm{mol}$ of $\mathrm{Pt})$ was used, the TON was 88.6 after $6 \mathrm{~h}$, which was lower than that of Cs-Pt-1 $(1.0 \mu \mathrm{mol}$ of Pt; TON of 209 after $6 \mathrm{~h}$ ) (Figure S1). Under $\geq 440 \mathrm{~nm}$ light irradiation, the Cs-Pt-1 (1.9 $\mu \mathrm{mol}$ of $\mathrm{Pt}) / \mathrm{EY}(5 \mu \mathrm{mol})$ system had a TOF of $70.4 \mathrm{~h}^{-1}$ (after $1 \mathrm{~h}$ ) for hydrogen evolution from $100 \mathrm{mM}$ aqueous TEOA solution ( $\mathrm{pH}$ 10) (Figure S2), which was higher than that of a colloidal Pt (1.92 $\mu \mathrm{mol}) / \mathrm{EY}(4.96 \mu \mathrm{mol})$ system for hydrogen evolution from $95 \mathrm{mM}$ aqueous TEOA solution (pH 10) under $>420 \mathrm{~nm}$ light irradiation (TOF of $\sim 26.0 \mathrm{~h}^{-1}$ after $1 \mathrm{~h}$ ) [10]. Here, we observed the stability of Cs-Pt-1 during the photoreactions by ${ }^{31} \mathrm{P}$ NMR spectroscopy. The ${ }^{31} \mathrm{P}$ NMR spectra in $\mathrm{D}_{2} \mathrm{O}$ of a $100 \mathrm{mM}$ aqueous TEOA solution containing Cs-Pt-1 and EY after 1, 2, and 3-h light irradiation are shown in Figure S3. A signal was observed at $-12.8 \mathrm{ppm}$, which was the same as that of as-prepared Cs-Pt-1, and no signal due to mono-lacunary $\alpha$-Keggin polyoxotungstate was observed. These results suggested that the platinum sites in Cs-Pt-1 were stable at least for a few hours under the present reaction conditions. Thus, the decrease in the reaction rates with time 
would predominantly be caused by decomposition of EY.

To investigate the effect of aluminum-coordinated polyoxometalates for the photoreactions, aluminum compounds K-Al-1, TMA-Al-2, KNa-Al-3, TMA-Al-4, and K-Al-5 were added to aqueous TEOA solutions containing Cs-Pt-1 and EY, as shown in Table 1 and Figure 2. The initial reaction rates were markedly decreased in the presence of the aluminum compounds. The TOFs of K-Al-1, TMA-Al-2, KNa-Al-3, TMA-Al-4, and K-Al-5 after $1 \mathrm{~h}$ were 170, 102, 116, 149 , and $61.7 \mathrm{~h}^{-1}$, respectively, which were lower than those in the absence of aluminum compounds $\left(315 \mathrm{~h}^{-1}\right)$. This might have been caused by an anionic repulsion between the platinumand aluminum-coordinated polyoxoanions. However, a clear deactivation was not observed after $12 \mathrm{~h}$, and the Cs-Pt-1/EY/K-Al-1 system showed a TON of 1042 after $12 \mathrm{~h}$, which was higher than those in the presence of TMA-Al-2 (652), KNa-Al-3 (821), TMA-Al-4 (853), and K-Al-5 (965). When $\mathrm{K}_{8}\left[\alpha-\mathrm{SiW}_{11} \mathrm{O}_{39}\right] \cdot 17 \mathrm{H}_{2} \mathrm{O}(2.5 \mu \mathrm{mol})$ was added to the mixture of EY and Cs-Pt-1 instead of the aluminum-coordinated polyoxometalates, the TON was 533 after $12 \mathrm{~h}$. Therefore, the highest activities were obtained in the presence of K-Al-1, and both aluminum site and internal atom in K-Al-1 affected the activities under these reaction conditions.

Under $\geq 440 \mathrm{~nm}$ light irradiation, the Cs-Pt-1 $(0.2 \mu \mathrm{mol}$ of Pt)/EY $(2.5 \mu \mathrm{mol}) / \mathbf{K}-\mathbf{A l}-1$ (2.5 $\mu \mathrm{mol}$ ) system produced $69.8 \mu \mathrm{mol}$ of hydrogen after $12 \mathrm{~h}$ from a $100 \mathrm{mM}$ aqueous TEOA solution at $\mathrm{pH}$ 7.0, and the TON became 698, as shown in Figure S4. No reaction was observed in the absence of EY under $\geq 440 \mathrm{~nm}$ light irradiation, which showed that the platinum sites in Cs-Pt-1 worked as a co-catalyst. For the colloidal Pt $(1.92 \mu \mathrm{mol}) / \mathrm{EY}(4.96 \mu \mathrm{mol})$ system, the initial rates increased with the addition of K-Al-1 $(96 \mu \mathrm{mol})$ [10]. However, the TON after $5 \mathrm{~h}$ was $\sim 235$ for hydrogen evolution from $95 \mathrm{mM}$ aqueous TEOA solution ( $\mathrm{pH} 7$ ) under $>420 \mathrm{~nm}$ light irradiation, which was lower than that of the Cs-Pt-1/EY/K-Al-1 system (TON of 256 after 5 h) that was observed under $\geq 440 \mathrm{~nm}$ light irradiation.

The UV-Vis spectrum of a mixture of Cs-Pt-1 $(0.2 \mu \mathrm{mol}$ of Pt), EY $(2.5 \mu \mathrm{mol})$, and K-Al-1 $(2.5 \mu \mathrm{mol})$ in $100 \mathrm{mM}$ aqueous TEOA solution at $\mathrm{pH} 7$ is shown in Figure S5(a). All bands observed in the spectrum were the same as those of EY; thus, the bands due to Cs-Pt-1 and KAl-1 were not observed because they were hidden by some large bands of EY. When the mixture was irradiated by light $(\geq 400 \mathrm{~nm})$, a large band at approximately $520 \mathrm{~nm}$ was sifted to approximately $490 \mathrm{~nm}$, which was assigned to a fluorescein-like species [10,16] (Figure S5(b)). The shift was observed at least after 1-h light irradiation, and the absorbance of a band at $490 \mathrm{~nm}$ gradually decreased with time. Similar changes in UV-Vis spectra were observed in the presence 
of TMA-Al-2, KNa-Al-3, TMA-Al-4, and K-Al-5. In the absence of aluminum-coordinated polyoxometalates, the all bands due to EY and fluorescein-like species completely disappeared after $6 \mathrm{~h}$ (Figure S5(c)). These results showed that aluminum-coordinated polyoxometalates remarkably stabilized EY and/or fluorescein-like species; however, it was reported that the activity of a fluorescein-like species was far lower than that of EY for hydrogen evolution from water [10]. Thus, a steady hydrogen production over a long-term of light irradiation would not be only caused by the stabilization of EY and/or fluorescein-like species. For the UV-vis measurements, a broad band at around $670 \mathrm{~nm}$ due to a heteropoly blue species was also observed for Cs-Pt-1/EY and EY/K-Al-1/cisplatin systems in a $100 \mathrm{mM}$ aqueous TEOA solution at $\mathrm{pH} 7$ after 1-h and 3-h light irradiation, as shown in Figure S6. As previously reported for Kegginstructure heteropoly blue anions $/ \mathrm{Pt} / \mathrm{TiO}_{2}$ system [17], a heteropoly blue species can act as a photosensitizer for hydrogen evolution from water under light irradiation (>420 nm). In addition, a rapid deactivation observed for Cs-Pt-1/EY system was prevented at a higher platinum concentration, as shown in Figure S1. These results suggested that a heteropoly blue species derived from Cs-Pt-1 and K-Al-1 would compensate for the decline in hydrogen production.

When titanium dioxide (anatase:rutile $=80: 20 ; 50 \mathrm{mg})$ was added to the Cs-Pt-1 $(0.2 \mu \mathrm{mol}$ of $\mathrm{Pt}) / \mathrm{EY}(2.5 \mu \mathrm{mol}) / \mathbf{K}-\mathbf{A l}-1(2.5 \mu \mathrm{mol})$ system, the initial rates significantly increased under light irradiation ( $\geq 400 \mathrm{~nm}, \geq 440 \mathrm{~nm}$, and $\geq 500 \mathrm{~nm}$ ), and a steady rate of hydrogen evolution was observed over $12 \mathrm{~h}$ (Figure 3). An induction period was observed under $\geq 440 \mathrm{~nm}$ and $\geq 500 \mathrm{~nm}$ light irradiation; however, it disappeared by using the Cs-Pt-1/EY/K-Al-1/TiO 2 system after 6-h light irradiation, as shown in Figure S7. The amounts of EY did not exert an effect to accelerate the initial rates. These results suggested that the process in a formation of heteropoly blue species affected the initial reaction rates. The amounts of hydrogen evolved after $12 \mathrm{~h}$ were 235.9, 160.7, and $24.1 \mu \mathrm{mol}$ (with TONs of 2359, 1607, and 241), respectively. The TOFs after $1 \mathrm{~h}$ were 339 $\mathrm{h}^{-1}$ (under $\geq 400 \mathrm{~nm}$ light irradiation) and $92.6 \mathrm{~h}^{-1}$ (under $\geq 440 \mathrm{~nm}$ light irradiation). Although it is difficult to draw a simple comparison, the TOFs of various photocatalytic system containing dyes and platinum, e.g., bn $(\mathrm{OH})_{2}$-modified $\mathrm{TiO}_{2}(0.1 \mathrm{wt} \% \mathrm{Pt})\left(\mathrm{bn}(\mathrm{OH})_{2}=1,1^{\prime}\right.$-binaphthalene2,2'-diol) [18], Pt(dcbpy)(met)/platinized $\mathrm{TiO}_{2}$ (dcbpy = 4,4'-dicarboxyl-2,2'-bipyridine; met $=$ cis-1,2-dicarbomethoxyethylene-1,2-dithiolate) [19], EY sensitized mesoporous-assembled $\mathrm{Pt} / \mathrm{TiO}_{2}$ [20], $\mathrm{Ru}_{2}$ (bpy) ${ }_{4} \mathrm{~L}_{1}-\mathrm{PF}_{6}, \mathrm{Pt} / \mathrm{TiO}_{2}$ (bpy = 2,2'-bipyridine, $\mathrm{L}=\mu$-4,4'-azo-benzene carboxylic acid) [21], ruthenium(II)-bipyridyl dyes/ $/ \mathrm{Pt} / \mathrm{TiO}_{2}$ [22], EY/SiW ${ }_{11} \mathrm{O}_{39}{ }^{8-} / \mathrm{Pt} / \mathrm{TiO}_{2}$ [23], Kegginstructure heteropoly blue anions/Pt/ $\mathrm{TiO}_{2}$ [17], EY/Pt/nitrogen-doped $\mathrm{TiO}_{2}$ [24], coumarin or carbazole dyes/Pt/TiO 2 or $\mathrm{H}_{4} \mathrm{Nb}_{6} \mathrm{O}_{17}$ [25], EY/Rose Bengal (RB)/Pt/graphene [26], RB/Pt/layered 
double hydroxide [27], platinum nanoparticles inside the cavities of a fourth-generation polyamidoamine dendrimer decorated with $\left[\mathrm{Ru}(\mathrm{bpy})_{3}\right]^{2+}$ units [28], and cobalt(II)tetraphenylporphyrin/methylviologen/Pt-loaded poly (L-glutamate) [29], were lower than $90 \mathrm{~h}^{-1}$ for hydrogen evolution from aqueous solutions containing TEOA, diethanolamine, EDTA.2Na, methanol, glycerol, triiodide/iodide, or ascorbic acid under visible light irradiation $(\lambda=>400,>410, \geq 420,>430 \mathrm{~nm}$, and $410 \mathrm{~nm}<\lambda<800 \mathrm{~nm})$. In contrast, the TOFs of $\mathrm{EY} / \mathrm{Pt} /$ modified $\mathrm{TiO}_{2}$ with sulfate and phosphate [30], $\mathrm{EY} / \mathrm{K}_{7}\left[\mathrm{Co}^{\mathrm{III}} \mathrm{Co}^{\mathrm{II}}\left(\mathrm{H}_{2} \mathrm{O}\right) \mathrm{W}_{11} \mathrm{O}_{39}\right] / \mathrm{Pt}[31]$, [RuL(bpy) 2 ( $\left.\mathrm{PF}_{6}\right)_{2} / \mathrm{Pt} / \mathrm{TiO}_{2}$ (L = 2-hydroxyl-5-(imidazo-[4,5-f]-1,10-phenanthrolin) benzoic acid [32], $\mathrm{Ru}(\mathrm{bpy})_{2}\left(4,4^{\prime}-\left(\mathrm{PO}_{3} \mathrm{H}_{2}\right)_{2} \mathrm{bpy}\right)^{2+} / \mathrm{Pt} /$ hexaniobate nanoscrolls or acid-restacked calcium niobate nanosheets [33], and metal-free organic dyes containing benzo[b]phenothiazine/ $\mathrm{Pt} / \mathrm{TiO}{ }_{2}$ [34] were in the range $100-840 \mathrm{~h}^{-1}$ for hydrogen evolution from aqueous TEOA and EDTA solutions under visible light irradiation $(\lambda=>400$ and $\geq 420 \mathrm{~nm})$; however, the rates rapidly decreased after a few hours. Therefore, the Cs-Pt-1/EY/K-Al-1/TiO 2 photocatalytic system achieved high TOFs and steady hydrogen production over a long-term of light irradiation.

A probable energy diagram for the Cs-Pt-1/EY/K-Al-1/TiO 2 system is shown in Figure S8. At the initial step, EY absorb photon energy to produce the excited $\mathrm{EY}^{*}$, and it injects electrons into the conduction band of $\mathrm{TiO}_{2}$ and/or the tungsten sites in Cs-Pt-1 and K-Al-1 to form a heteropoly blue species. The electrons injected into the conduction band of $\mathrm{TiO}_{2}$ are consumed by reduction of water at the platinum sites in Cs-Pt-1 to form hydrogen. During the photoreactions, EY transformed into a fluorescein-like species. Both a fluorescein-like species and heteropoly blue species acted as a photosensitizer instead of EY in the later stage.

(Insert Table 1 and Figures 2 and 3 here)

\section{Conclusion}

We investigated a novel photocatalytic system constructed using EY, Keggin-type diplatinum(II)- and mono-aluminum(III)-coordinated polyoxometalates, and titanium dioxide for hydrogen production from aqueous TEOA solutions under visible light irradiation $(\lambda=\geq 400$ $\mathrm{nm}, \geq 440 \mathrm{~nm}$, and $\geq 500 \mathrm{~nm}$ ). The system achieved a steady hydrogen production during a longterm light irradiation with highly effective utilization of the platinum sites in a wide visible region. 


\section{Acknowledgments}

This work was supported by the Ministry of Education, Culture, Sports, Science and Technology of Japan. We also acknowledge Mr. Wataru Unno (Shizuoka University) for the synthesis and characterization of K-Al-1 and TMA-Al-4, and Mr. Daisuke Miyamae (Shizuoka University) for the UV-vis and NMR measurements.

\section{References}

[1] Fujishima A, Honda K (1972) Nature 238:37.

[2] Abe R (2010) J Photochem Photobiol C: Photochem Rev 11:179.

[3] Maeda K, Domen K (2010) J Phys Chem Lett 1:2655.

[4] Hisatomi T, Kubota J, Domen K (2014) Chem Soc Rev 43:7520.

[5] Yang J, Wang D, Han H, Li C (2013) Acc Chem Res 46:1900.

[6] M. T. Pope, Heteropoly and Isopoly Oxometalates (Springer-Verlag, Berlin, 1983).

[7] Pope MT, Müller A (1991) Angew Chem Int Ed Engl 30:34.

[8] Polyoxometalates: From Platonic Solids to Anti-Retroviral Activity, eds. M. T. Pope and A. Müller (Kluwer Academic Publishers, Dordrecht, The Netherlands, 1994).

[9] Kato CN, Morii Y, Hattori S, Nakayama R, Makino Y, Uno H (2012) Dalton Trans $41: 10021$.

[10] Liu X, Li Y, Peng S, Lu G, Li S (2012) Int J Hydrogen Energy 37:12150.

[11] Ma R-H, Wei T-T, Zhao C-Y (2011) Huaxue Shiji 33:307.

[12] Kato CN, Nagami M, Ukai N (2013) Appl Catal A: General 452:69.

[13] Kato CN, Katayama Y, Nagami M, Kato M, Yamasaki M (2010) Dalton Trans 39:11469.

[14] Kato CN, Kashiwagi T, Unno W, Nakagawa M, Uno H (2014) Inorg Chem 53:4824.

[15] Tézé A, Hervé G. (1977) J Inorg Nucl Chem 39:999.

[16] Kimura K, Miwa T, Imamura M (1970) Bull Chem Soc Jpn 43:1329.

[17] Fu N, Lu G (2009) Appl Surf Sci 255:4378.

[18] Ikeda S, Abe C, Torimoto T, Ohtani B (2003) J Photochem Photobiol A: Chem 160:61.

[19] Zhang J, Du P, Schneider J, Jarosz P, Eisenberg R (2007) J Am Chem Soc 129:7726.

[20] Sreethawong T, Junbua C, Chavadej S (2009) J Power Sources 190:513.

[21] Peng T, Dai K, Yi H, Ke D, Cai P, Zan L (2008) Chem Phys Lett 460:216.

[22] Peng T, Ke D, Cai P, Dai K, Ma L, Zan L (2008) J Power Sources 180:498. 
[23] Liu X, Li Y, Peng S, Lu G, Li S (2013) Int J Hydrogen Energy 38:11709.

[24] Li Y, Xie C, Peng S, Lu G, Li S (2008) J Mol Catal A: Chem 282:117.

[25] Abe R, Shinmei K, Koumura N, Hara K, Ohtani B (2013) J Am Chem Soc 135:16872 .

[26] Min S, Lu G (2012) Int J Hydrogen Energy 37:10564.

[27] Hong J, Wang Y, Pan J, Zhong Z, Xu R (2011) Nanoscale 3:4655.

[28] Ravotto L, Mazzaro R, Natali M, Ortolani L, Morandi V, Ceroni P, Bergamini G (2014) J Phys Chem Lett 5:798.

[29] Ngweniform P, Kusumoto Y, Ikeda M, Somekawa S, Ahmmad B (2007) J Photochem Photobiol A: Chem 189:198.

[30] Liu X, Li Y, Peng S, Lu G, Li S (2013) Photochem Photobiol Sci 12:1903.

[31] Zhao J, Ding Y, Wei J, Du X, Yu Y, Han R (2014) Int J Hydrogen Energy 39:18908.

[32] Zheng H-Q, Yong H, Ou-Yang T, Fan Y-T, Hou H-W (2013) Int J Hydrogen Energy $38: 12938$.

[33] Maeda K, Eguchi M, Lee S-HA, Youngblood WJ, Hata H, Mallouk TE (2009) J Phys Chem C 113:7962.

[34] Watanabe M, Hagiwara H, Iribe A, Ogata Y, Shiomi K, Staykov A, Ida S, Tanaka K, Ishihara T (2014) J Mater Chem A 2:12952. 


\section{Figure captions}

Figure 1. Polyhedral representations of polyoxoanions (a) $\left[\alpha-\mathrm{PW}_{11} \mathrm{O}_{39}\left\{c i s-\mathrm{Pt}\left(\mathrm{NH}_{3}\right)_{2}\right\}_{2}\right]^{3-}(\mathbf{P t}-$ 1), (b) $\left[\alpha-\mathrm{SiW}_{11}\left\{\mathrm{Al}\left(\mathrm{OH}_{2}\right)\right\} \mathrm{O}_{39}\right]^{5-}$ (Al-1) and $\left[\alpha-\mathrm{PW}_{11}\left\{\mathrm{Al}\left(\mathrm{OH}_{2}\right)\right\} \mathrm{O}_{39}\right]^{4-}$ (Al-2), (c) [(A$\left.\left.\mathrm{PW}_{9} \mathrm{O}_{34}\right)_{2}\left\{\mathrm{~W}(\mathrm{OH})\left(\mathrm{OH}_{2}\right)\right\}\left\{\mathrm{Al}(\mathrm{OH})\left(\mathrm{OH}_{2}\right)\right\}\left\{\mathrm{Al}(\mu-\mathrm{OH})\left(\mathrm{OH}_{2}\right)_{2}\right\}_{2}\right]^{7-} \quad$ (Al-3), (d) $\quad\left[\alpha_{2}-\right.$ $\left.\mathrm{P}_{2} \mathrm{~W}_{17}\left\{\mathrm{Al}\left(\mathrm{OH}_{2}\right)\right\} \mathrm{O}_{61}\right]^{7-}(\mathbf{A l}-4)$, and (e) $\left[\mathrm{B}-\alpha-\mathrm{H}_{3} \mathrm{P}_{2} \mathrm{~W}_{15}\left\{\mathrm{Al}\left(\mathrm{OH}_{2}\right)\right\}_{3} \mathrm{O}_{59}\right]^{6-}$ (Al-5). The $\mathrm{WO}_{6}$ and $\mathrm{AlO}_{6}$ units are represented by white and blue octahedra, respectively. The internal $\mathrm{PO}_{4}$ and $\mathrm{SiO}_{4}$ units are represented by red tetrahedra. Al-1, Al-2, and Al-4 were monomeric compounds where an aluminum ion was located at the A-site of the $\alpha$-Keggin structure and at the B-site of the $\alpha$ Dawson structure, respectively. Polyoxoanion Al-3 was a dimeric aluminum complex where two 6-coordinate aluminum ions are linked by two bridging hydroxyl groups and four water molecules, i.e., $\left[\mathrm{Al}^{\mathrm{III}} 2(\mu-\mathrm{OH})_{2}\left(\mathrm{OH}_{2}\right)_{4}\right]^{4+}$. Units of a 6-coordinate tungsten and aluminum ions linked with a hydroxyl group and a water molecule, i.e., $\left[\mathrm{W}(\mathrm{OH})\left(\mathrm{OH}_{2}\right)\right]^{5+}$ and $\left[\mathrm{Al}(\mathrm{OH})\left(\mathrm{OH}_{2}\right)\right]^{2+}$ were sandwiched between two tri-lacunary $\alpha$-Keggin polyoxotungstates. Polyoxoanion Al-5 was also a monomeric compound where three aluminum ions were located at the B-site of the $\alpha$-Dawson structure.

Figure 2. Time course for hydrogen evolution from aqueous TEOA solution under visible light irradiation catalyzed by Cs-Pt-1 and EY without aluminum-coordinated polyoxometalates $(\diamond)$, and in the presence of K-Al-1 (•), TMA-Al-2 (•), KNa-Al-3 (•), TMA-Al-4 (०), and K-Al-5 (). Reaction conditions are shown in Table 1.

Figure 3. Time course for hydrogen evolution from aqueous TEOA solution under visible light irradiation. Reaction conditions: Cs-Pt-1 (0.2 $\mu \mathrm{mol}$ of Pt), EY $(2.5 \mu \mathrm{mol}), \mathbf{K}-\mathbf{A l}-1$ ( $2.5 \mu \mathrm{mol})$, $\mathrm{TiO}_{2}$ (anatase: rutile $\left.=80: 20\right) 50 \mathrm{mg}, 100 \mathrm{mM}$ TEOA aqueous solution $(10 \mathrm{~mL}, \mathrm{pH}$ 7), light irradiation at ((a) $\geq 400 \mathrm{~nm},(\mathrm{~b}) \geq 440 \mathrm{~nm}$, and (c) $\geq 500 \mathrm{~nm})$ at $25^{\circ} \mathrm{C}$. 
$\underline{\text { Table } 1 \text { Hydrogen evolution from TEOA aqueous solution catalyzed by platinum complexes and Eosin Y under visible light irradiation }{ }^{\mathrm{a}}}$

\begin{tabular}{|c|c|c|c|c|}
\hline Pt complexes ( $\mu \mathrm{mol}$ of $\mathrm{Pt}$ atom) & Al-POMs & Reaction time (h) & $\mathrm{H}_{2}(\mu \mathrm{mol})$ & $\mathrm{TON}^{\mathrm{b}}$ \\
\hline Cs-Pt-1 (0.2) & - & $\begin{array}{l}1 \\
6\end{array}$ & $\begin{array}{l}31.5 \\
78.1\end{array}$ & $\begin{array}{l}315 \\
781\end{array}$ \\
\hline Cs-Pt-1 (1.0) & - & $\begin{array}{l}1 \\
6\end{array}$ & $\begin{array}{r}35.4 \\
104.4\end{array}$ & $\begin{array}{l}70.7 \\
210\end{array}$ \\
\hline cisplatin (1.0) & - & $\begin{array}{l}1 \\
6\end{array}$ & $\begin{array}{l}34.2 \\
44.3\end{array}$ & $\begin{array}{l}68.4 \\
88.6\end{array}$ \\
\hline Cs-Pt-1 (0.2) & K-Al-1 & $\begin{array}{c}1 \\
6 \\
12 \\
\end{array}$ & $\begin{array}{r}17.0 \\
71.5 \\
104.2 \\
\end{array}$ & $\begin{array}{r}170 \\
715 \\
1042 \\
\end{array}$ \\
\hline Cs-Pt-1 (0.2) & TMA-Al-2 & $\begin{array}{c}1 \\
6 \\
12 \\
\end{array}$ & $\begin{array}{l}10.2 \\
38.5 \\
65.2\end{array}$ & $\begin{array}{l}102 \\
385 \\
652 \\
\end{array}$ \\
\hline Cs-Pt-1 (0.2) & KNa-Al-3 & $\begin{array}{c}1 \\
6 \\
12 \\
\end{array}$ & $\begin{array}{l}11.6 \\
63.6 \\
82.1\end{array}$ & $\begin{array}{l}116 \\
636 \\
821 \\
\end{array}$ \\
\hline Cs-Pt-1 (0.2) & TMA-Al-4 & $\begin{array}{c}1 \\
6 \\
12\end{array}$ & $\begin{array}{l}14.9 \\
64.4 \\
85.3\end{array}$ & $\begin{array}{l}149 \\
644 \\
853\end{array}$ \\
\hline Cs-Pt-1 (0.2) & K-Al-5 & $\begin{array}{c}1 \\
6 \\
12 \\
\end{array}$ & $\begin{array}{l}6.17 \\
61.2 \\
96.5\end{array}$ & $\begin{array}{l}61.7 \\
612 \\
965 \\
\end{array}$ \\
\hline- & K-Al-1 & $\begin{array}{l}1 \\
6\end{array}$ & $\begin{array}{l}\text { trace } \\
\text { trace }\end{array}$ & $\begin{array}{l}- \\
-\end{array}$ \\
\hline
\end{tabular}

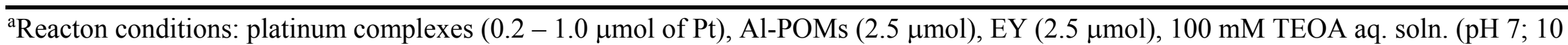
$\mathrm{mL}), 25^{\circ} \mathrm{C}$, light $(\geq 400 \mathrm{~nm})$

${ }^{\mathrm{b}}$ Turnover number $(\mathrm{TON})=2\left[\mathrm{H}_{2}\right.$ evolved $\left.(\mathrm{mol})\right] /[\mathrm{Pt}$ atoms $(\mathrm{mol})]$ 
(a)

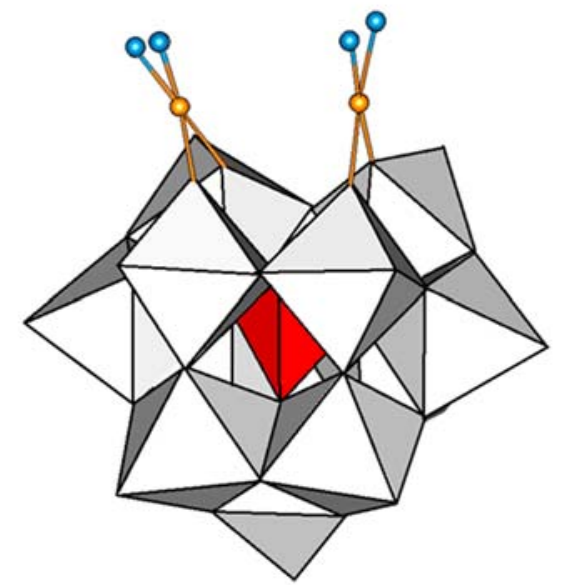

(b)

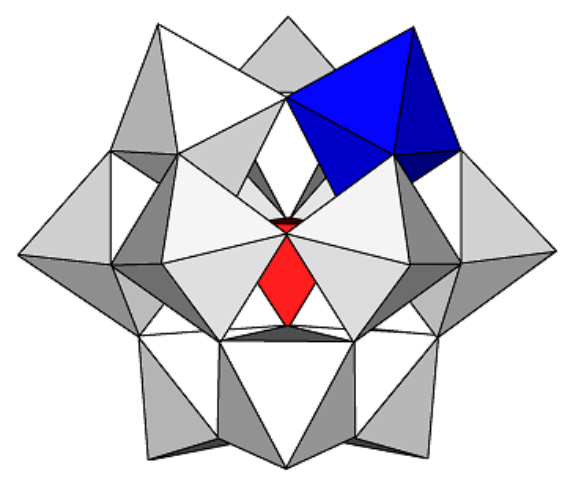

(c)

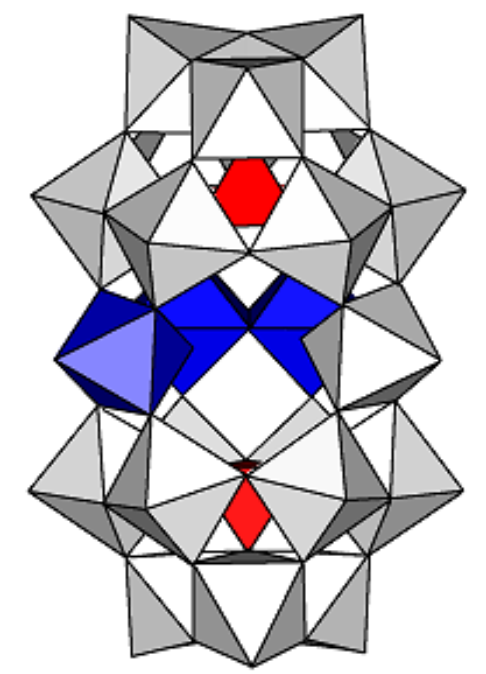

(d)

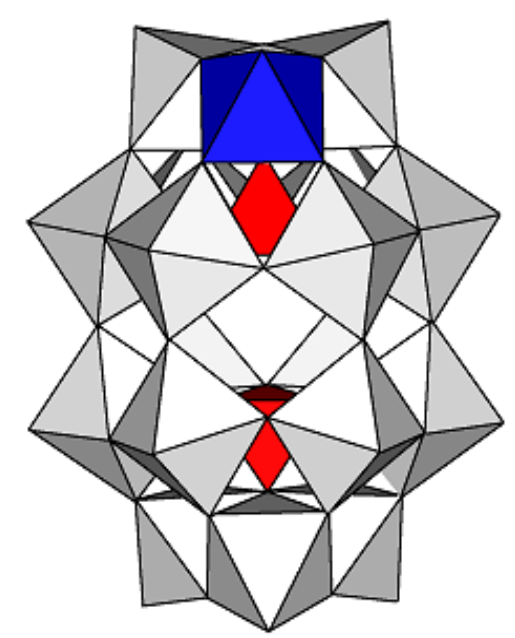

(e)

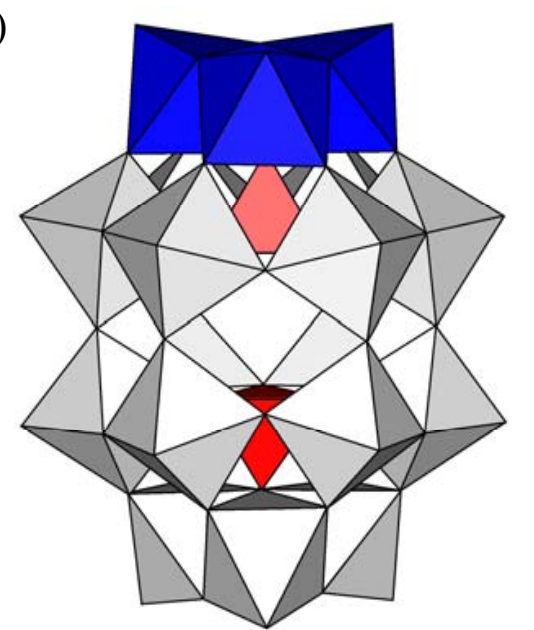

Fig. 1 


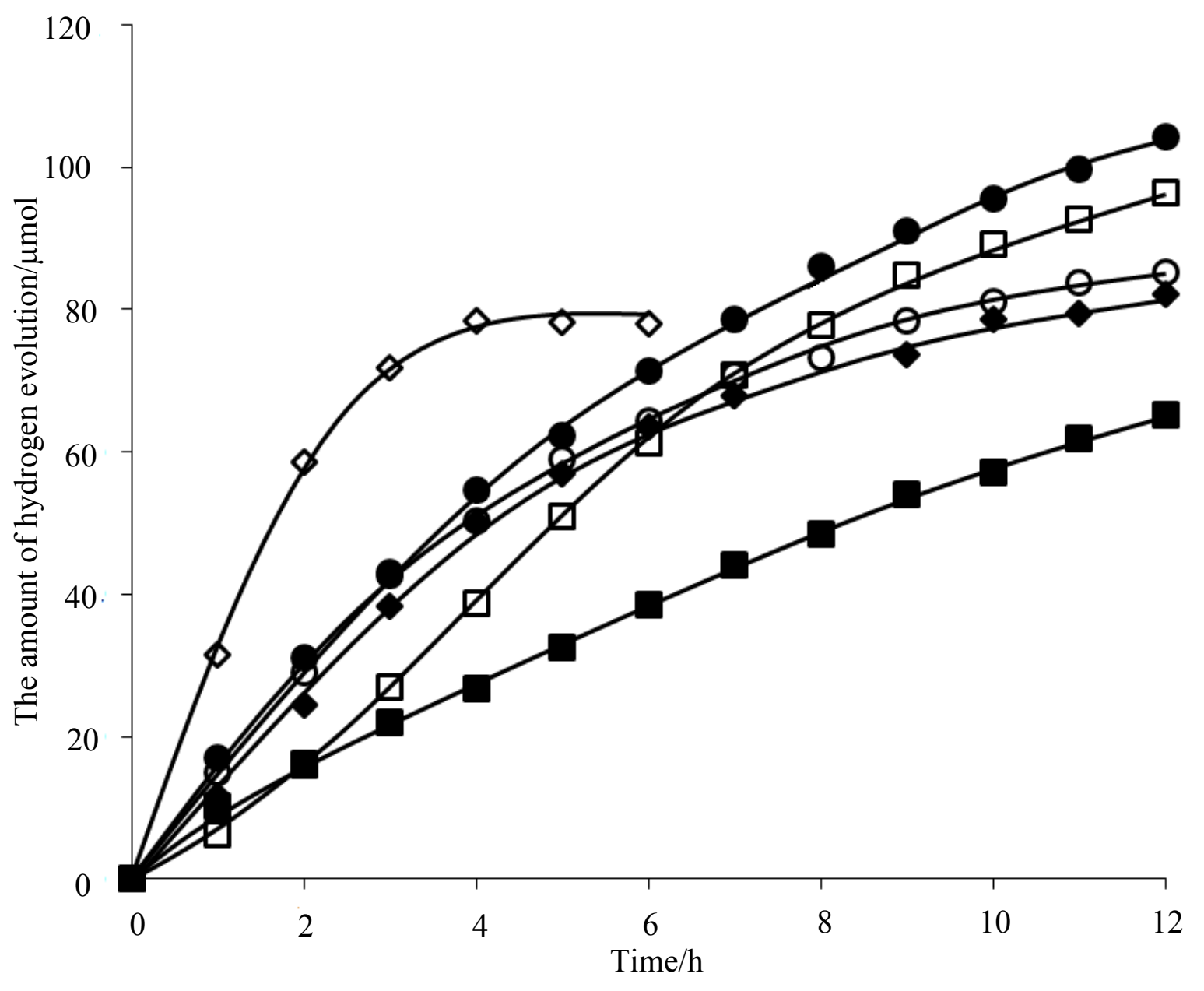

Fig. 2 

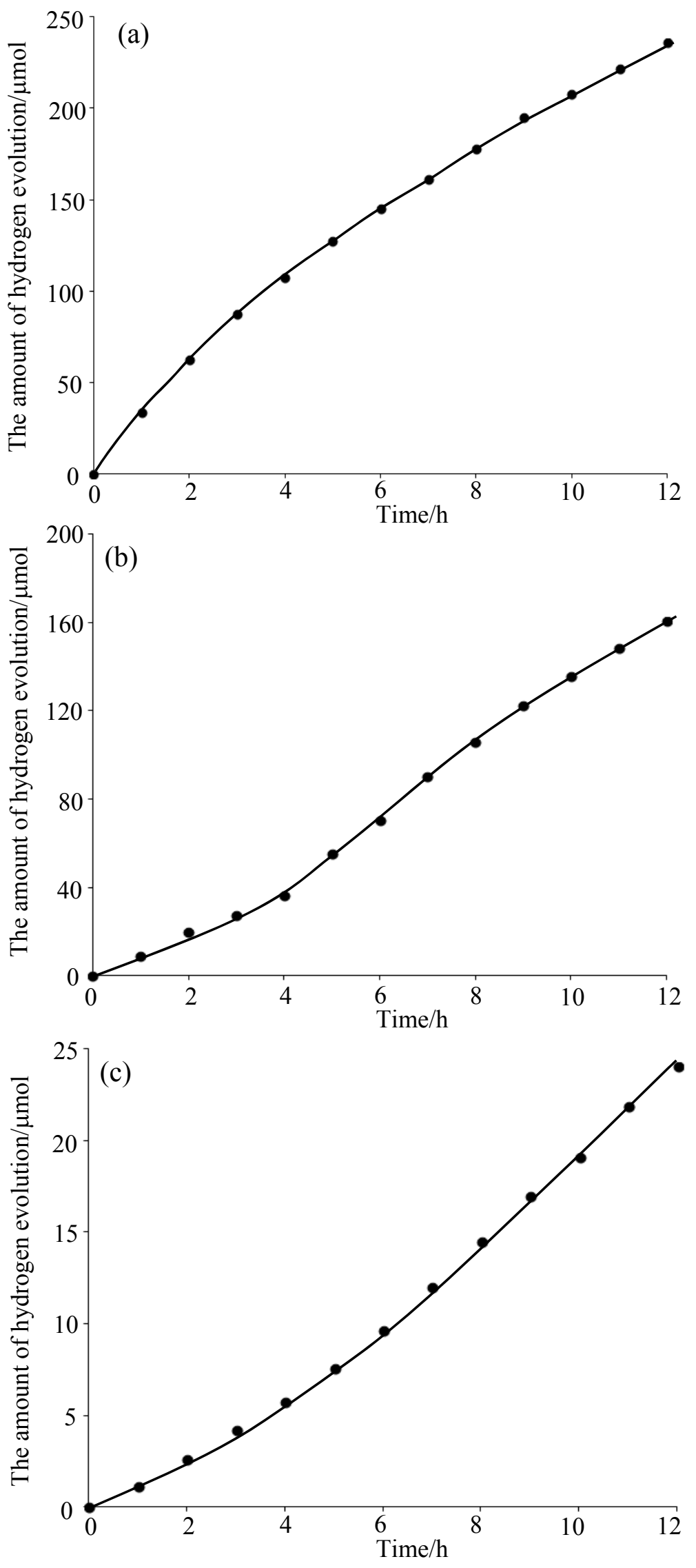

Fig. 3 